\title{
SIMULASI DAYA DUKUNG LINGKUNGAN DI PULAU GILI KETAPANG- PROBOLINGGO DENGAN MENGANDALKAN CURAH HUJAN SEBAGAI PEMENUHAN KEBUTUHAN AIR
}

\section{SIMULATION OF ENVIRONMENTAL CARRYING CAPACITY IN GILI KETAPANG ISLAND -PROBOLINGGO WITH RELY ON RAINFALL AS THE FULFILLMENT OF WATER DEMAND}

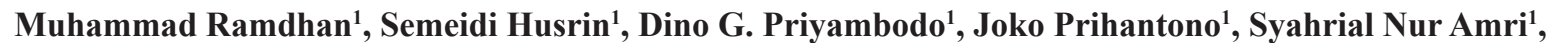 \\ Hari Prihatno ${ }^{1}$, Nasir Sudirman ${ }^{1}$, Hasanuddin ${ }^{2} \&$ Sachrul Iswahyudi $^{2}$ \\ ${ }^{1}$ Pusat Riset Kelautan, Badan Riset dan Sumber Daya Manusia - KKP \\ ${ }^{2}$ Pusat Penelitian Oseanografi - LIPI \\ e-mail : m.ramdhan@kkp.go.id
}

Diterima tanggal: 18 April 2018 ; diterima setelah perbaikan: 9 April 2019 ; Disetujui tanggal: 15 April 2019 DOI: http://dx.doi.org/10.15578/jkn.v14i1.6861

\begin{abstract}
ABSTRAK
Hujan merupakan salah satu sumberdaya air yang penting bagi kehidupan manusia. Keseimbangan lingkungan dapat diketahui dari ketersediaan sumber air yang berguna untuk memenuhi kebutuhan masyarakat. Daya dukung lingkungan adalah kemampuan lingkungan untuk menunjang kehidupan manusia dan makhluk hidup lainnya. Salah satu cara menentukan daya dukung lingkungan adalah dengan pendekatan ketersediaan dan kebutuhan air. Tujuan dari penelitian ini adalah melakukan simulasi terhadap status daya dukung lingkungan berdasarkan ketersediaan air bulanan dari curah hujan dan kebutuhan air di Pulau Gili Ketapang-Probolinggo dalam satu tahun. Metode yang digunakan untuk mengetahui daya dukung lingkungan adalah analisis kuantitatif melalui perbandingan antara penghitungan ketersediaan air dan kebutuhan air. Hasil penghitungan status daya dukung lingkungan berdasarkan ketersediaan air dan kebutuhan air di Gili Ketapang apabila dihitung berdasarkan kebutuhan layak air minum 130 liter/orang/hari adalah defisit sebesar 33.389.799,47 liter/bulan.
\end{abstract}

Kata kunci: Daya dukung lingkungan, Pulai Gili Ketapang, curah hujan, penentuan kebutuhan air.

\section{ABSTRACT}

Rainfall is one of the important water resources for human life. Environmental balance can be known from the availability of water sources that are useful to meet the needs of the people. Environmental carrying capacity is the ability of the environment to support human life and other living things. One way to determine the environmental carrying capacity is to approach the availability and needs of water. The purpose of this research is to simulate the environmental carrying capacity based on monthly water availability from rainfall and water demand in Gili Ketapang-Probolionggo Island in one year. The method used to determine environmental carrying capacity is quantitative analysis through comparison between the calculation of water availability and water demand. The result of calculation of environmental carrying capacity based on water availability and water demand in Gili Ketapang when calculated based on water basic needs of 130 liters / person / day is a deficit waters of 33,389,799.47 liters / month.

Keywords: Environmental carrying capacity, Gili Ketapang, ranfall, water demand.

Simulasi Daya Dukung Lingkungan di Pulau Gili Ketapang - Probolinggo dengan Mengandalkan Curah Hujan Sebagai Pemenuhan Kebutuhan Air - Muhammad Ramdhan, Semeidi Husrin, Dino G. Pryambodo, Joko Prihantono, Syahrial Nur Amri, Hari Prihatno, Nasir Sudirman, Hasanuddin \& Sachrul Iswahyudi 25 


\section{PENDAHULUAN}

Masalah lingkungan menjadi isu global saat ini dikarenakan tidak adanya keseimbangan antara makhluk hidup yang tinggal di dalamnya dan ketersediaan daya dukung lingkungan (GFN, 2010). Daya dukung lingkungan yang berasal dari alam merupakan faktor yang turut serta dalam pembentukan kesejahteraan masyarakat. Penentuan besarnya daya dukung lingkungan dilakukan dengan cara mengetahui kapasitas yang dimiliki lingkungan untuk memenuhi dan mendukung kegiatan manusia pengguna ruang dalam rangka menjamin kelangsungan hidupnya (Setyaningrum \& Prasetya, 2017).

Air merupakan salah satu sumber daya lingkungan yang berharga. Makhluk hidup tidak bisa hidup tanpa air. Air disebut sumber daya karena kemampuannya untuk memenuhi atau menangani kebutuhan manusia dan juga menjadi sumber persediaan, menunjang dan memberi bantuan terhadap kehidupan. Air dapat dikategorikan sebagai sumber daya tak terbarukan, apabila kemampuan memulihkan diri lebih kecil daripada volume pemanfaatannya. Oleh karena itu, sumber air tanah yang terbatas dapatdikategorikan sebagai sumber air tak terbarukan. Sebaliknya, menjadi sumber daya terbarukan, apabila kemampuan memulihkan diri lebih besardari pada volume pemakaiannya. Air sungai yang melimpah dikategorikan sebagai sumber daya terbarukan (Fauzi,
2004).

Simulasi pemodelan dapat dilakukan untuk menghitung nilai daya dukung lingkungan (Qing et al., 2013, Safuan et al., 2013). Tujuan tulisanini yaitu untuk memprediksi status daya dukung lingkungan berdasarkan ketersedian dan kebutuhan air di Gili Ketapang dengan menggunakan simulasi data di tahun 2013. Daya dukung akan dihitung dengan pendekatan perbandingan antara ketersediaan dan kebutuhan air. Penelitian sebelumnya mengenai prediksi data ini telah dilakukan oleh Ramdhan et al. (2018), untuk wilayah perkotaan. Penelitian ini lebih spesifik dilakukan pada wilayah urban di pulau kecil.

\section{BAHAN DAN METODE}

\section{Lokasi Penelitian}

Gili Ketapang terletak di wilayah Kabupaten Probolinggo. Secara geografis terletak pada koordinat $113^{\circ} 14^{\prime} 9,5^{\prime \prime} \mathrm{BT}-113^{\circ} 16^{\prime} 2,4^{\prime \prime}$ BT dan $7^{\circ} 40^{\prime}$ 13,1'"LS-7 $41^{\prime} 20,1$ ' $L S$, dan merupakan salah satu pulau kecil diantara pulau Jawa dan Madura. Masyarakat lokal lebih mengenalnya dengan sebutan Pulau Gili. Pulau ini hanya memiliki satu desa saja yaitu Desa Gili Ketapang. Di sebelah utara Gili Ketapang berbatasan dengan Selat Madura, di sebelah timurdibatasi oleh Selat Madura dan Kecamatan Dringu, sebelah barat dibatasi oleh Selat Maduradan Kecamatan Pilang, sebelah selatan dibatasi oleh Selat Madura, dan Kota

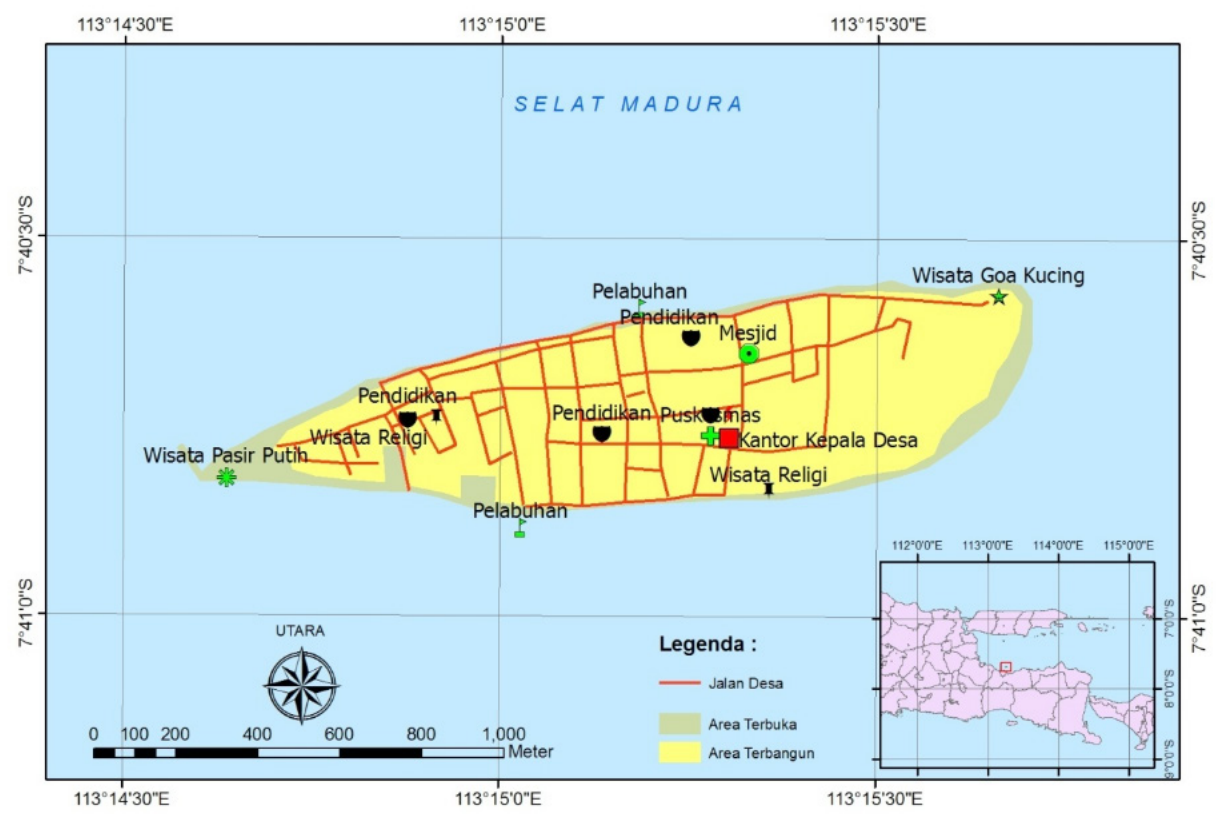

Gambar 1. Peta Lokasi Gili Ketapang (Sumber: digitasi citra GoogleEarth). Figure 1. Location Map of Gili Ketapang (Source: digitized GoogleEarth image).

JURNAL KELAUTAN NASIONAL, Vol. 14, No 1, April 2019, Hal. 25-32 
Probolinggo, wilayah KecamatanMayangan.

Desa Gili Ketapang tersebut dapat ditempuh dalam waktu tigapuluhmenit dari Pelabuhan Tanjung Tembaga Probolinggo dengan menaiki kapal yang bermuatan kurang lebih dua puluh orang. Jadwal keberangkatan kapalmenuju Desa Gili tidak pasti. Keberangkatan kapal bergantung pada perkiraan nahkoda, jika ombak besar maka nahkoda tidak akan memberangkatkan kapalmenuju Desa Gili (Mayasari, 2014).

\section{Pengumpulan Data}

Penentuan daya dukung lingkungan pada penelitian ini dilakukan berdasarkan perbandingan antara kebutuhan dan ketersediaan air dengan variabel yang digunakan yaitu: Variabel ketersediaan air dengan indikator: koefisien limpasan tutupan lahan; nilai rata-rata curah hujan bulanan; dan luas wilayah (Prastowo, 2010). Variabel kebutuhan air dengan indikator: jumlah penduduk dan kebutuhan air untuk hidup layak.

Data yang digunakan dalam penelitian ini yaitu :

1. Data jumlah penduduk Pulau Gili Ketapang dalam angka tahun 2013dariBadan Pusat Statistik;

2. Peta Rupa Bumi Indonesia skala 1:25.000 Pulau Gili Ketapang, dariBIG;

3. Peta Tutupan Lahan Hasil Klasifikasi Citra Landsat ; 4. Data Curah hujan bulanan Pulau Gili Ketapang dari satelit TRMM, diunduh dari https://disc.gsfc.nasa.gov/

\section{Analisis Data}

Analisis data spasial dilakukan menggunakan perangkat lunak pengolahan sistem informasi geografis (SIG), sedangkan untuk data nonspasial dianalisis dengan menggunakan perangkat lunak yang memiliki kemampuan kalkulasi dan pembuatan grafik. Pengolahan data nonspasial dilakukan untuk menghitung koefisien limpasan, ketersediaan air, memproyeksikan data penentu kebutuhan air (jumlah penduduk), kebutuhan air, dan untuk mengetahui rasio dan status daya dukung lingkungan tahun 2013 di pulau Gili Ketapang. Secara skematik proses analisis data disajikan pada Gambar 2.

\section{Pengolahan Data \\ Data Jumlah Penduduk}

Proyeksi penduduk tahun-tahun setelah 2013 dapat dilakukan secara arithmatic rate of growth (pertumbuhan penduduk secara aritmatik) dengan asumsi pertumbuhan penduduk dengan jumlah sama setiap tahun (Setyaningrum \& Prasetya, 2017). Bentuk matematis model aritmetik untuk kasus pulau Gili Ketapang adalah sebagai berikut:

$\mathrm{Pn}=\mathrm{Po}(1+\mathrm{r} . \mathrm{n})$

di mana,

$\mathrm{Pn}=$ Jumlah penduduk pada tahun ke-n;

Po $=8.424$ jiwa Jumlah penduduk pada tahun awal (dasar);

$r=1.19 \%$, Angka pertumbuhan penduduk; dan

$\mathrm{n}=$ Periode waktu yang akan di prediksi, dalam satuan tahun.

\section{Data Curah Hujan}

Data curah hujan bulanan selama 1 tahun (12 bulan) di Pulau Gili Ketapang diambil dari data Tropical Rainfall Measuring Mission (TRMM). Data TRMM adalah data presipitasi (hujan) yang didapat dari satelit meteorologi TRMM dengan sensornya PR (Precipitation Radar), TMI (TRMM Microwave Imager), VIRS (Visible and Infrared Scanner),CERES (Clouds and the Earth's Radiant Energi System), dan LIS (Lightning Imaging Sensor).Data hujan yang digunakan adalah data bulanan level 3 dengan resolusi spasial $0,25^{\circ} \times 0,25^{\circ}$. Type 3B43 digunakan dalam penelitian ini karena merupakan kompilasi dari data radiowave satelit dengan didukung oleh data stasiun-stasiun curah hujan yang terpasang di permukaan bumi (Syaifullah, 2014). Gambar 3. menunjukkan sebaran curah hujan di Pulau Gili Ketapang pada 2013. Curah hujan tertingggi terjadi pada bulan Januari sebesar 467,07 mm/bulan. Sedangkan tingkat curah hujan terendah ada di bulan Agustus yaitu 19,43 mm/bulan.

\section{Tutupan Lahan}

Data tutupan lahan diperoleh dari hasil interpretasi citra

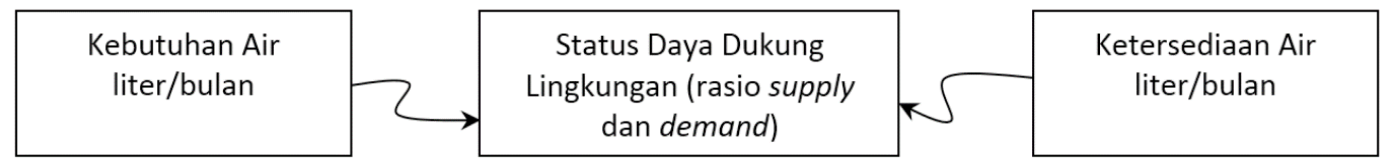

Gambar 2. Alur Pikir Analisis Status daya dukung lingkungan dengan pendekatan ketersediaan dan kebutuhan air Figure 2. Alur Pikir Analysis Status of carrying capacity of the environment with the approach of availability and need for water.

Simulasi Daya Dukung Lingkungan di Pulau Gili Ketapang - Probolinggo dengan Mengandalkan Curah Hujan Sebagai Pemenuhan Kebutuhan Air - Muhammad Ramdhan, Semeidi Husrin, Dino G. Pryambodo, Joko Prihantono, Syahrial Nur Amri, Hari Prihatno, Nasir Sudirman, Hasanuddin \& Sachrul Iswahyudi 


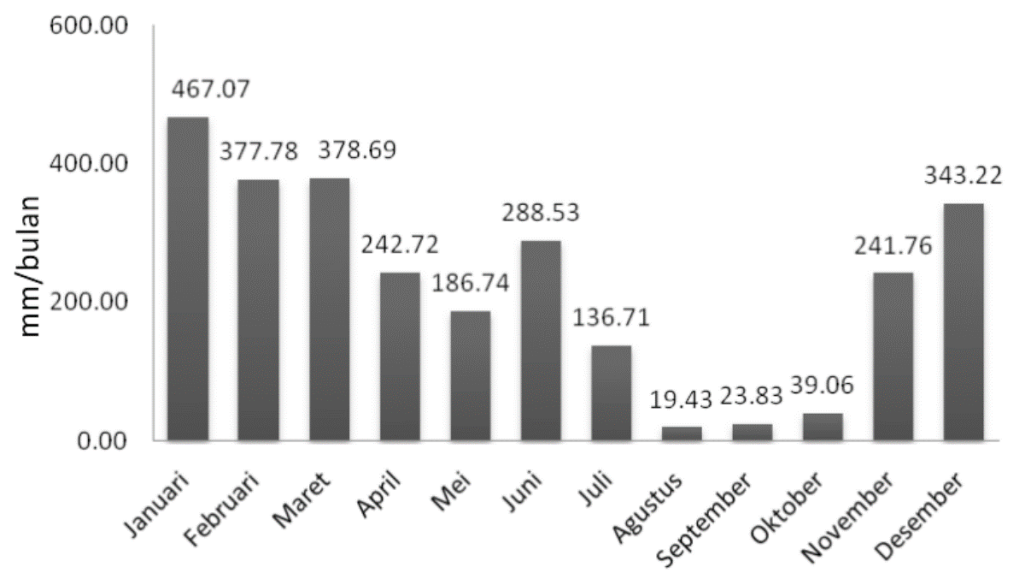

Gambar 3. Grafik Data TRMM curah hujan bulanan di Gili Ketapang tahun 2013. (diolah dari gscf.nasa.gov).

Figure 3. Graphs of monthly rainfall TRMM data in Gili Ketapang in 2013. (processed from gscf.nasa.gov).

landsat tahun 2013 dibantu dari citra Google Earth dan data BPS 2013. Adapun komposisi tutupan lahan dari data BPS terlihat dalam tabel 1. Dari data Google Earth diperoleh komposisi lahan terbuka adalah 15,58\%, sedangkan lahan terbangun adalah $84,42 \%$.

Tutupan lahan akan menentukan nilai koefisien bagi limpasasn air hujan. MENLH (2009) telah menentukan besaran koefisien limpasan air hujan (C) untuk masingmasing lahan sebagaimana dalam Tabel 2.

Nilai $\mathrm{Ci}$ modus maksimum untuk masing-masing kelompok tutupan lahan diambil sebagai koefisien pengali pada model. Diasumsikan bahwa semakin banyak limpasan air hujan yang terjadi, semakin banyak air yang dapat dimanfaatkan untuk memenuhi kebutuhan warga Pulau Gili Ketapang.

\section{Ketersediaan Air}

Analisis ketersediaan air di Pulau Gili Ketapang memperhitungkan ketersedian air dengan mengacu pada Permen LH No. 17 Tahun 2009 tentang Pedoman Penentuan Daya Dukung Lingkungan Hidup dalam Penataan Ruang Wilayah, sebagai berikut:
$C=\Sigma(C i \times A i) / \Sigma A i$

$$
S A=C \times R \times A
$$

di mana,

S A $=$ ketersediaan air (liter/bulan);

$\mathrm{C}=$ koefisien limpasan tertimbang;

$\mathrm{Ci}=$ koefisien limpasan penggunaan lahan i;

Ai = luas penggunaan lahan $\mathrm{i}(\mathrm{ha})$;

$\mathrm{R} \quad=$ rata-rata aljabar curah hujan bulanan wilayah (mm/bulan) TRMM;

$=$ luas wilayah (ha);

\section{Kebutuhan Air}

Kebutuhan air adalah sejumlah air yang digunakan untuk berbagai peruntukkan atau kegiatan masyarakat dalam wilayah tertentu. Adapun metode untuk menghitung kebutuhan air mengacu pada Permen LH No. 17 Tahun 2009, yakni:

\section{$D A=N \times K H L A$}

di mana,

DA $=$ Total Kebutuhan Air ( $\mathrm{m}^{3} /$ tahun);

$\mathrm{N} \quad=$ Jumlah Penduduk (Jiwa);

Tabel 1. Tutupan lahan di Pulau Gili Ketapang

Table 1. Land cover on Gili Ketapang Island

\begin{tabular}{lllll}
\hline Bangunan/ & \multicolumn{4}{c}{ Luas Tutupan Lahan P. Gili Ketapang (Ha) } \\
Perumahan & $\begin{array}{l}\text { Tegalan/ } \\
\text { Pekarangan }\end{array}$ & Perkuburan & Lain-lain & Jumlah \\
\hline 13,0 & 33,0 & 8,0 & 7,0 & 61,0 \\
\hline
\end{tabular}

Sumber: Interpretasi Citra Landsat, BPS

JURNAL KELAUTAN NASIONAL, Vol. 14, No 1, April 2019, Hal. 25-32 
Tabel 2. Nilai koefisien limpasan air hujan berdasarkan Permen LH 17/2009

Table 2. The value of rainwater runoff coefficient is based on Permen LH 17/2009

\begin{tabular}{|c|c|c|c|c|}
\hline No. & Deskripsi permukaan & $\mathbf{C i}$ & $\begin{array}{l}\text { Kelompok } \\
\text { Tutupan } \\
\text { Lahan }\end{array}$ & $\begin{array}{l}\text { Modus } \\
\text { Nilai Ci } \\
\text { Maksimal }\end{array}$ \\
\hline 1 & Kota, jalan aspal, atap genteng & $0,7-0,9$ & \multirow{5}{*}{ Terbangun } & \multirow{5}{*}{0,9} \\
\hline 2 & Kawasan industri & $0,5-0,9$ & & \\
\hline 3 & Pemukiman multi unit, pertokoan & $0,6-0,7$ & & \\
\hline 4 & Kompleks perumahan & $0,4-0,6$ & & \\
\hline 5 & Villa & $0,3-0,5$ & & \\
\hline 6 & Taman, pemakaman & $0,1-0,3$ & & \\
\hline \multirow[t]{4}{*}{7} & Pekarangan tanah berat: & & & \\
\hline & a) $>7 \%$ & $0,25-0,35$ & & \\
\hline & b) $2-7 \%$ & $0,18-0,22$ & & \\
\hline & c) $<2 \%$ & $0,13-0,17$ & & \\
\hline \multirow[t]{4}{*}{8} & Pekarangan tanah ringan: & & & \\
\hline & a) $>7 \%$ & $0,15-0.2$ & Terbuka 0,35 & \\
\hline & b) $2-7 \%$ & $0,10-0,15$ & & \\
\hline & c) $<2 \%$ & $0,05-0,10$ & & \\
\hline 9 & Lahan berat & 0,4 & & \\
\hline 10 & Padang rumput & 0,35 & & \\
\hline 11 & Lahan budidaya pertanian & 0,3 & & \\
\hline 12 & Hutan produksi & 0,18 & & \\
\hline
\end{tabular}

KHLA $=$ Kebutuhan air untuk hidup layak

Kebutuhan air layak akan menggunakan standar PU yaitu rata-rata 130 liter/orang/hari. Adapun komposisi pemanfaatan air di wilayah tipikal desa seperti Gili Ketapang adalah seperti pada tabel 3.

\section{Status Daya Dukung Lingkungan}

Penentuan daya dukung lingkungan dilakukan dengan pendekatan supply and demand. Status daya dukung ini dapat ditentukan setelah diketahui besarnya ketersediaan air dan kebutuhan air pada daerah penelitian. Perbandingan antara kondisi ketersediaan air dengan kebutuhan air pada wilayah penelitian menjadi dasar dalan penetapan status daya dukung lingkungan. Jika rasio $>1$ berarti kondisi supply lebih besar dari pada demand, sehingga daya dukung masih baik. Sedangkan jika rasio $<1$ berarti demand lebih banyak daripada supply sehingga kondisi lingkungan terlampaui daya dukungnya.

Tabel 3. Komposisi keperluan air per hari

Table 3. The composition of water needs per day

\begin{tabular}{llll}
\hline No & Aktivitas & $\begin{array}{l}\text { Keperluan air } \\
\text { (liter/orang/hari) }\end{array}$ \\
\hline 1 & Mandi & 86,3 & 66,38 \\
2 & Mencuci Pakaian & 17,0 & 13,08 \\
3 & Memasak/Minum & 2,4 & 1,85 \\
4 & Mencuci Alat Dapur & 3,7 & 2,85 \\
5 & Mencuci Lantai & 1,0 & 0,77 \\
6 & Wudlu' & 17,5 & 13,46 \\
7 & Mencuci Kendaraan & 1,1 & 0,85 \\
8 & Menyiran Tanaman & 0,4 & 0,31 \\
9 & Pemanfaatan Air Lain-lain 0,6 & 0,46 \\
& Total & 130 & 100 \\
\hline Sumber: Poediastoeti (2013) & &
\end{tabular}

Simulasi Daya Dukung Lingkungan di Pulau Gili Ketapang - Probolinggo dengan Mengandalkan Curah Hujan Sebagai Pemenuhan Kebutuhan Air - Muhammad Ramdhan, Semeidi Husrin, Dino G. Pryambodo, Joko Prihantono, 


\section{HASIL DAN PEMBAHASAN}

\section{Penduduk Gili Ketapang}

Gili Ketapang merupakan pulau dengan banyak aktivitas. Hal ini terlihat dari komposisi kegiatan/ pekerjaan dari penduduknya yang beraneka macam. BPS (2013) mencatat mayoritas penduduk bekerja sebagai pedagang, diikuti oleh buruh industri rumah tangga, jasa angkutan, pensiunan, buruh bangunan, nelayan dan lain-lain. BPS (2013) mencatat jumlah penduduk Desa Gili Ketapang sebesar 8.424 jiwa dengan jumlah Rumah Tangga 1.614 KK. Ratarata per Rumah Tangga di Gili Ketapang memiliki sekitar 5 orang anggota keluarga. Angka kelahiran di Gili Ketapangpada tahun 2013 mencapai 2,85\%. Sedangkan Angka kematiannya 1,66\%. Sehingga angka pertumbuhan di P. Gili Ketapang pada 2013 sebesar $1,19 \%$.

\section{Ketersediaan Air}

Ketersediaan air merupakan fungsi waktu, yang melimpah/berlebih pada musim hujan dan berkurang pada musim kemarau. Untuk jumlah air secara keseluruhan di seluruh dunia adalah tetap. Persediaan totalnya tidak dapat dikurangi atau ditambah, namun dengan usaha-usaha pengembangan dan pengelolaan sumber daya air, penyebarannya menurut waktu dan ruang dapat diatur sesuai dengan kebutuhannya (Putuhena, 2004). Jumlah ketersediaan air sangat berkaitan dengan curah hujan dan penggunaan lahan di Pulau Gili Ketapang. Diasumsikan penduduk Gili Ketapang hanya memanfaatkan limpasan air hujan yang jatuh ke wilayah pulau untuk memenuhi kebutuhan hidup sehari-hari.

\section{Kebutuhan Air}

Faktor penentu dalam menghitung kebutuhan air dalam penelitian ini yaitu jumlah penduduk dan kebutuhan air per kapita untuk Pulau Gili Ketapang. Kebutuhan air untuk standar Permen LH 17/2009 mengikuti perhitungan untuk pemenuhan standar layak air bagi masyarakat Indonesia dikalikan dengan angka faktor pengaman sebanyak $2 \mathrm{x}$ lipat, besarnya adalah $1600 \mathrm{~m}^{3}$ air/kapita/tahun. Peraturan menteri ini memperhitungkan juga kebutuhan air virtual bagi penduduk. Hal ini berarti pemenuhan kebutuhan makanan pokok juga dihitung sebagai kebutuhan akan air. Untuk penelitian ini digunakan kebutuhan air menurut Poediastoeti (2013) yang mengacu pada kebutuhan air penduduk pedesaan dari Departemen PU, yaitu 130 liter/kapita/hari.

\section{Status Daya Dukung Lingkungan}

Analisis status daya dukung lingkungan dengan pendekatan air (SDDL-Air) merupakan rasio antara kondisi ketersediaan air dengan kebutuhan air yang ada di suatu wilayah. Semakin tinggi nilai ketersediaan air maka nilai rasio akan semakin besar, hal ini menunjukkan semakin terjaminnya kondisi ketersediaan sumber daya air untuk memenuhi kebutuhan masyarakat. Berdasarkan perbandingan ini didapatkan rasio SDDL-Air seperti ditunjukkan dalam Gambar 6. Angka rasio 1 dijadikan sebagai pembatas antara kondisi surplus sumber daya air dengan defisit sumber daya air.Jika nilai supply sama dengan demand, maka rasio akan sama dengan 1. Sehingga jika rasio $>1$ maka dikatakan kondisi surplus, sebaliknya jika rasio $<1$ maka kondisi defisit sumber daya air.

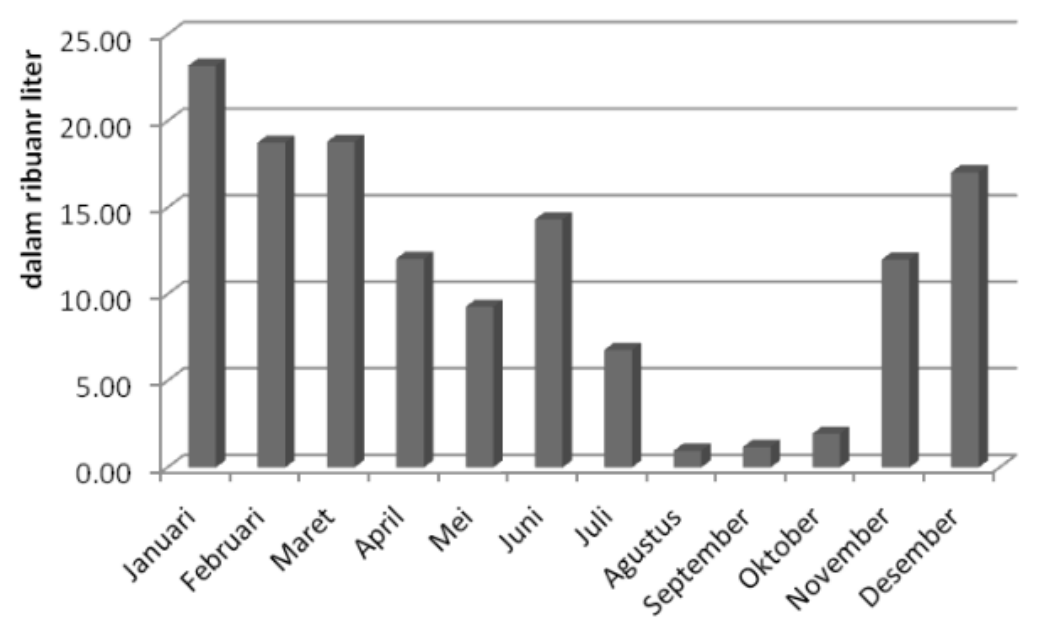

Gambar 4. Grafik ketersediaan air per bulan pada 2013 di Gili Ketapang. Figure 4. Graph of monthly water availability on 2013 in Gili Ketapang. 


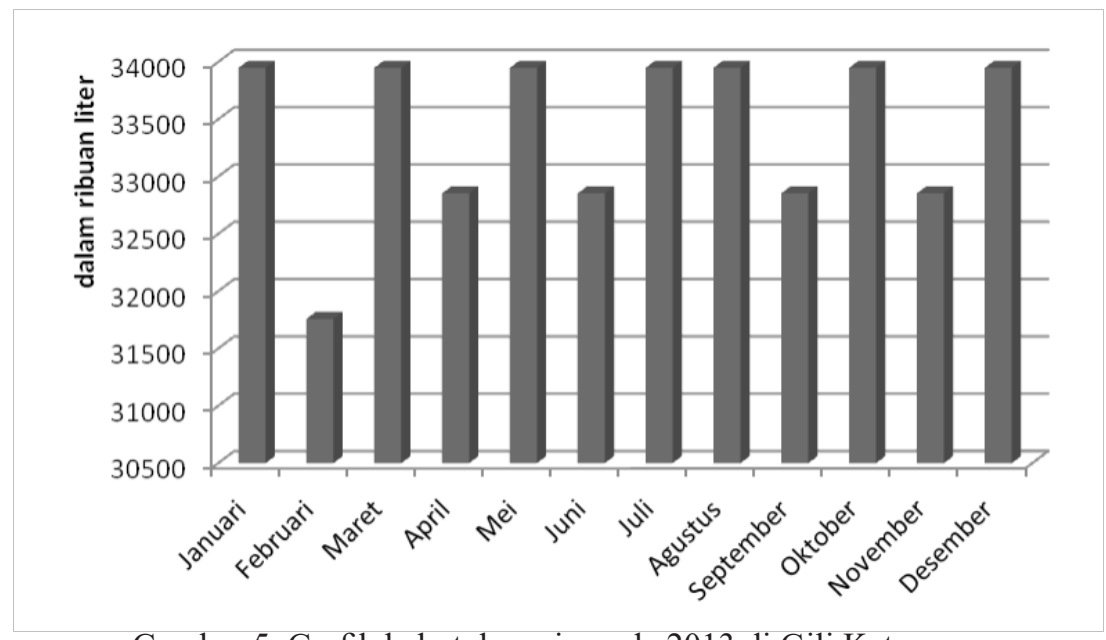

Gambar 5. Grafik kebutuhan air pada 2013 di Gili Ketapang.

Figure 5. 2013 water demand graph in Gili Ketapang.

Berdasarkan gambar diatas dapat dilihat bahwa bila menggunakan nilai angka kelayakan penggunaan air sebesar 130 liter/orang/hari. Maka pada 2013 di Pulau Gili Ketapang telah dalam kondisi defisit sumber daya air. Defisit terbesar terjadi pada bulan Agustus, dengan ketersediaan air 964,68 liter/bulan sedangkan kebutuhan sebanyak 33.948.720 liter/ bulan. Dibutuhkan rata-rata 33.389.799,47 liter/bulan air tambahan untuk memenuhi kebutuhan penduduk Pulau Gili Ketapang. Alternatif lain pemenuhan supply air baku untuk pulau Gili Ketapang harus dipikirkan, seperti potensi penggunaan air tanah dan penyulingan air laut. Hingga saat tulisan ini disusun, masyarakat Gili Ketapangmemenuhikebutuhan air bersihnyadarisaluran air PDAM yang di stok dari pulau Jawa.

\section{KESIMPULAN DAN SARAN}

Pulau Gili Ketapang telah disimulasikan status daya dukung lingkungan dengan pendekatan kebutuhan dan persediaan air. Angka kebutuhan menggunakan standar kebutuhan air yang layak bagi daerah pedesaan, yaitu sebesar 130 liter/orang/hari. Angka Ketersediaan diambil dari rata-rata bulanan curah hujan di Gili Ketapang pada 2013. Hasilnya adalah rasio angka kebutuhan dan ketersediaan air pada 2013 area Pulau Gili Ketapang jauh dari garis kecukupan. Pada saat ini masyarakat Gili Ketapang masih bisa memenuhi kebutuhan airnya, karena ada pasokan air dari daratan utama. Pengembangan alternatif pemenuhan air baku lain untuk Pulau Gili Ketapang perlu diperhatikan oleh masyaraka tsetempat, pemerintah daerah, akademisi dan pemangku kepentingan lainnya.

\section{UCAPAN TERIMA KASIH}

Ucapan terimakasih kami sampaikan kepada panitia seleksi Demand Driven Research Grant (DDRG) LIPI tahun 2018 yg telah memberikan dana penelitian. Juga kepada kepala pusat riset kelautan BRSDM KP atas bantuan dan fasilitas yg diberikan. Terakhir, kepada

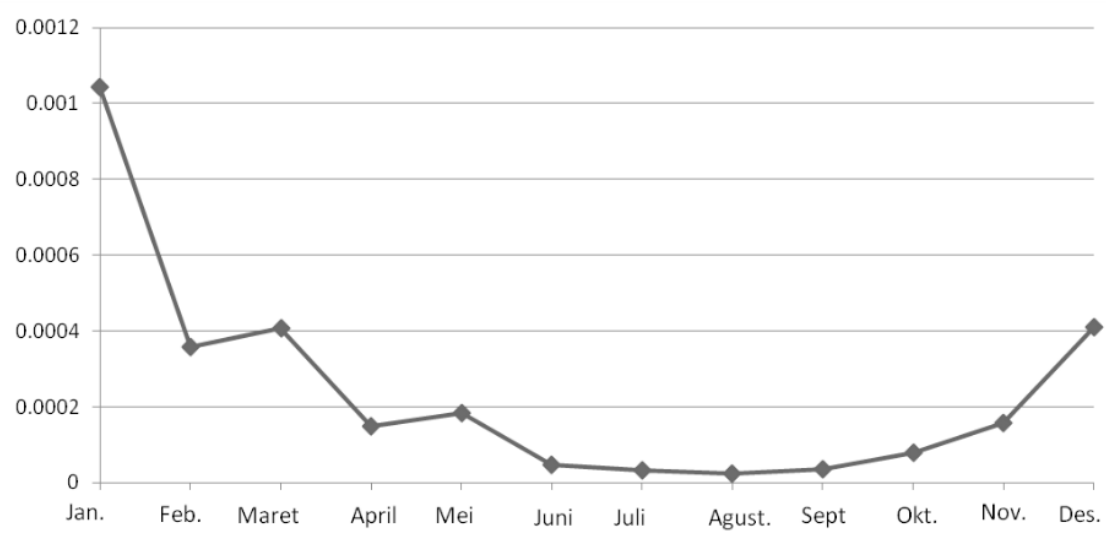

Gambar 6. Grafik Gili Ketapang pada 2013.

Figure 6. Gili Ketapang chart on 2013.

Simulasi Daya Dukung Lingkungan di Pulau Gili Ketapang - Probolinggo dengan Mengandalkan Curah Hujan Sebagai Pemenuhan Kebutuhan Air - Muhammad Ramdhan, Semeidi Husrin, Dino G. Pryambodo, Joko Prihantono, Syahrial Nur Amri, Hari Prihatno, Nasir Sudirman, Hasanuddin \& Sachrul Iswahyudi 
dewan redaksi JKN serta pihak reviewer kami ucapkan pula terimakasih atas kerjasamanya hingga tulisan ini dapat diterbitkan.

\section{DAFTAR PUSTAKA}

BPS. (2014).Wilayah Kecamatan Sumberasih dalam angka 2013, Badan Pusat Statistik, Kabupaten Probolinggo.

Fauzi. (2004). Ekonomi Sumber daya Alam dan Lingkungan, Teori dan Aplikasi, PT Gramedia Pustaka Utama, Jakarta.

GFN. (2010). The Ecological Wealth of Nations, Global Footprint Network, Oakland, California

Mayasari F. E. (2014). Penggunaan Bahasa Madura Di Desa Gili Ketapang, Kecamatan Sumberasih, Kabupaten Probolinggo: Kajian Sosiolinguistik, Skripsi, Universitas Airlangga, Surabaya.

MENLH. (2009). Peraturan Menteri Negara Lingkungan Hidup Nomor 17 Tahun 2009, Tentang Pedoman Penentuan Daya Dukung Lingkungan Hidup Dalam Penataan Ruang Wilayah, Deputi V MENLH Bidang Penaatan Lingkungan, Jakarta.

Meyers G., McIntosh P., Pigot L., \& Pook, M. (2007). The Years of El Niño, La Niña, and Interactions with the Tropical Indian Ocean, Journal of Climate, American Meteorological Society, 20, 2872-2880.

Poediastoeti, H. (2013). Pengaruh Kondisi Sosial Ekonomi Masyarakat Terhadap Pola Pemakaian Air Domestik, Jurnal Lingkungan-Sultan Agung, (1)1, 64-77.

Prastowo, (2010). Daya Dukung Lingkungan Aspek Sumber daya Air, Working Paper P $4 W$. Crestpent Press, Bogor.

Putuhena F. (2004). Ketersediaan dan Kebutuhan Air, Transformasi kebijakan pengelolaan sumber daya air, LIPI Press, Jakarta

Qing, Z. X., Hui, R., Qi, Y., Lan, H. E. C., \& Hui Y. H. (2013). Scenarios Simulation on Carrying Capacity of Water Resources in Kunming City, Procedia Earth and Planetary Science, 5, $107-112$.

Ramadhan, M., Suharnoto, Y., Tarigan, S. D., \& Arifin, H. S. (2018). Simulation of environmental carrying capacity in Bogor City, Indonesia, which rely on rainfall as water supply. AES Bioflux, 10(2):68-78.

Safuan, H. M., Towers, I. N., Javanoski, Z., \& Sidhu, H. S. (2013). Coupled logistic carrying capacity model, ANZIAM JOURNAL, 53, C172-C184

Samekto, C., \& Winata, E. S. (2010). Potensi Sumber Daya Air di Indonesia, Seminar Nasional: Aplikasi Teknologi Penyediaan Air Bersih untuk Kabupaten/ Kota di Indonesia, PTL-BPPT: Jakarta

Setyaningrum, N., \& Prasetya, G. A. (2017). Analisis Ketersediaan Dan Kebutuhan Air Untuk Daya Dukung Lingkungan: Studi Kasus di Kabupaten Bojonegoro, Prosiding Seminar Nasional Geomatika 2017: Inovasi Teknologi Penyediaan Informasi Geospasial untuk Pembangunan Berkelanjutan,Badan Informasi Geospasial, Cibinong.
Strahler, A, N., \& Strahler, A. H. (1984). Elements of Physical Geography, (4th ed.), John Wiley \& Sons.

Sutjahjo, N., Anggraini, F., \& Pamekas, R. (2011). Konsumsi Dan Pelanggan Air Minum Di Kota Besar dan Metropolitan, Jurnal Permukiman, 6(3), 138-146.

Syaifullah, M. D. (2014). Validasi Data TRMM Terhadap Data Curah Hujan Aktual di Tiga DAS di Indonesia, Jurnal Meteorologi Dan Geofisika, 15(2), 109-118.

JURNAL KELAUTAN NASIONAL, Vol. 14, No 1, April 2019, Hal. 25-32 